\title{
The Relationship between Sex Education and Sexual Behaviour in Adolescents
}

\author{
Hubungan antara Pendidikan Seksual dengan Perilaku Seksual pada Remaja
}

\author{
Nofi Susanti, Reinpal Falefi*, Tri Bayu Purnama \\ Public Health Faculty, Universitas Islam Negeri Sumatera Utara
}

DATA OF ARTICLE:

Received: 10 May 2021

Reviewed: 8 June 2021

Revised: 3 July 2021

Accepted: 8 July 2021

*CORRESPONDENCE:

reinpal.falefi@uinsu.ac.id

DOI:

10.18196/mmjkk.v21i2.11744

TYPE OF ARTICLE:

Research

\begin{abstract}
Adolescent sexual behavior remains a global problem with high reports of cases of adolescents behaving freely. The lack of knowledge about sexuality is caused by limited information, services, and advocacy. There has not been a reproductive health curriculum for adolescents in schools. Therefore, this study aims to determine the relationship between sex education and sexual behavior in adolescents. This research is a quantitative study with a cross-sectional design. The sampling was taken using a total sampling technique. The sample included all students of class X and XI, with a total of 102 people. The research instrument used a questionnaire. Data were analyzed using chi-square and multiple logistic regression. Bivariate analysis results showed that there was a relationship between sex education by parents, teachers, peers, and social media and sexual behavior. The results of multivariate analysis with logistic regression tests showed that sex education provided by parents was the most substantial relationship with sexual behavior. The study concluded that parents, teachers, and social media were associated with sex education. Extensive sex education from other trusted information could reduce pre-marital sexual activity among adolescents. Elaborating on external factors would implicate a good attitude and behavior in students.
\end{abstract}

Keywords: adolescent; sex education; sexual behavior

Kata Kunci: remaja; pendidikan seks; perilaku seksual 


\section{INTRODUCTION}

In 2014, the number of cases of sexually transmitted infections in Indonesia reached 5608 cases. The incidence of sexually transmitted infections and symptoms is experienced by $12 \%$ of women aged $15-49$ reported to have active sexual intercourse. ${ }^{1}$ Sexually transmitted diseases in adolescents are very likely to be caused by unhealthy sexual behavior. ${ }^{2}$ Sex education is defined as information about humans in the sexual context conveyed in formal and informal ways at the target education level. This information includes explanations of the process of fertilization, pregnancy, childbirth, behavior, sexual intercourse, and other aspects. ${ }^{3}$ Limited information about sex education impacts the information around the community to be scientifically proven. ${ }^{4}$

The majority of teenagers obtain invalid information in terms of reference sources. ${ }^{5}$ That information can be obtained from the source of Friends in a school environment (45\%), Teachers (16.3\%), health workers (12.8\%), parents (8.7\%), and obtained from religious leaders (6.8\%). According to the Women's Protection Agency and the Family Planning Area (Badan Perlindungan Perempuan dan Keluarga Berencana Daerah (PPKBD)) in 2015, 40\% of Junior and senior high school students have been having intercourse before marriage. Moreover, some of them have been accustomed to or often have intercourse with their girlfriends or friends, so that the intervention of sexual education in adolescence is essential. The number of teenagers in Indonesia that amounted to 46 million is very potential for future investment in Indonesia. ${ }^{6}$

Adolescence is defined as the transition period to the maturity process commencing from the time of the children who began since the age of twelve, which then ended in the early twenty years. ${ }^{7}$ Meanwhile, Anna Freud stated that the psychosexual development process and the progression of change to people in the crowd and life goals and ideals could signify a youth change. ${ }^{8}$ Adolescent Sexual behavior is influenced by Knowledge. Knowledge of misperception and lack of knowledge will ignite curiosity and tend to prove self-proving. ${ }^{9}$

Preliminary study results showed that several students held hands at school even though the school had already applied the prohibited dating rules. Based on these variables, poor premarital behavior is associated with sex education in adolescents. Understanding the sex education relationship with sexual behavior in adolescents might trigger problems. It could contribute to determining the dominant role in sexual education in adolescents. Based on this background, this study aims to identify the relationship between sex education and sexual behavior in adolescents.

\section{MATERIALS AND METHOD}

\section{Research settings}

The study used a quantitative research method with a cross-sectional design to identify a dynamic correlation of sex education risk factors in adolescents at the same time. A cross-sectional design is in line with the research purpose, which aimed to identify the role of sex educational relationship with sexual behavior in high school teenagers. This research was conducted in high school by considering the population and exact location and never had the exact research-related location. This research was conducted after receiving ethical research permission from the institution and approved by the site of high school research. This study was conducted for 3 months.

\section{Population and samples}

The population in this study was all students of class X (Ten) and Class XI (eleven). This research used two proportion sample sizes to measure the total sampling in this study. 102 samples were recruited, and 12 students were excluded due to the national examination. The inclusion criteria included students in grades $\mathrm{X}, \mathrm{XI}$, and XII, willing to be participants, and high school students.

\section{Data Collection Method}

The research was conducted after researchers obtained approval from the principal as a person in charge of educational institutions and informed consent to students as an agreement to be the research subject. Information about the objectives, benefits, and procedures of implementing research was explained by the enumerator prior to the research. In this study, all subjects were willing to participate in the data collection using an anonymity questionnaire and only using initials.

The researchers defined sex behavior in this study as an impaling about sex, watching pornographic films, and other sexual acts such as kissing cheeks, lip kissing, holding hands, hugs, fingering sensitive and 
intimate body parts. As predictors, the researchers used parental sex education, peer education, teacher education, and social media exposure.

\section{Research instruments}

The study used a questionnaire to collect data from the students-the questionnaire made by the researchers was based on theory and has passed the validity and reliability $(r=0.734)$. Several questions consisted of 22 questions with closed types to measure sexual education. Parents education considered no internal problem among parents, dating prohibition, education on sexuality, attention to child behavior, directing behavior such as worship, freedom of opinion, and provision of time to family quality. Good peer education was categorized as using time with peers, delivering fatigue with peers, accepting information, and making decisions with peers. Teacher education was categorized as school activities, religious activities and educational media, associations, and information about sexual education and problem-solving. Education by social media was categorized well as the source of information obtained from radio, television, newspapers, magazines, videos, etc.

\section{Data Analysis}

This study deployed a chi-square test to prove the hypothesis. Logistic regression for multivariate analysis was used to estimate the model by using an odd ratio.

\section{Ethical Clearance}

This research was approved by the Health Research Ethics Committee, Islamic University of North Sumatra, No.121/EC/KEPK.UINSU/III/2021.

\section{RESULT}

There are 102 students participated in this study and ultimately finished the whole question in the questionnaire. Table 1 shows the characteristics of respondents of the study. There were more female participants (55.9\%) than males (44.1\%), and the majority of participants were $16-17$ years old (67.7\%) from the exact sciences department (45.1\%). The rest were students from the social sciences $(28.4 \%)$ and none of both (26.5\%). The students in the 'none of both' group were the student from the first level in the school (basic level).

Table 2 shows that students with deviating sex behaviors like impaling about sex, watching pornographic films, and other sexual acts such as kissing cheeks, lip kissing, hugs, holding hands, fingering sensitive and intimate body parts occurred in students with a percentage of $88.2 \%$. It contrasts with the findings on the role of education of parents, teachers, peers, and social media that were of good majority.

Table 1. Characteristics of Participants

\begin{tabular}{lll}
\hline Variable & N & $\%$ \\
\hline Gender & & \\
Male & 45 & 44.1 \\
Female & 57 & 55.9 \\
Age & & \\
15 & 19 & 18.6 \\
16 & 38 & 37.3 \\
17 & 31 & 30.4 \\
18 & 11 & 10.8 \\
19 & 1 & 1.0 \\
20 & 2 & 2.0 \\
Department & & \\
Science & & 45.1 \\
Sosial & 46 & 28.4 \\
None of Both & 29 & 26.5 \\
\hline
\end{tabular}


Table 2. Distribution of Sex Behavior in Students by Educator

\begin{tabular}{lcc}
\hline Variable & N & $\%$ \\
\hline Sex behavior & 12 & 11.8 \\
Good & 90 & 88.2 \\
Bad & & \\
Education by parents & 96 & 94.1 \\
Good & 6 & 5.9 \\
Bad & & \\
Education by teachers & 98 & 96.1 \\
Good & 4 & 3.9 \\
Bad & & \\
Education by peers & 84 & 82.4 \\
Good & 18 & 17.6 \\
Bad & & \\
Education by social media & 88 & 86.3 \\
Good & 14 & 13.7 \\
Bad & & \\
\hline
\end{tabular}

In Table 3, it is revealed that the influence of social media did not significantly affect risky sex behavior (PR 1.647 (0.854-2.030)). The risky sex behavior triggered by the influence of sex education in adolescents is more widely gained indirect education such as sex education is not risky in parents, teachers, and peers.

Multivariate Logistic Regression Analysis we see in Table 4 revealed that the sex education which parents conducted as the most protective sex education against sex behavior in students is 6.8 times compared with sex education in teachers of 1.3 times.

Tabel 3. The Relationship of Sex Education with Sexual Behaviour in Adolescents

\begin{tabular}{lcccc}
\hline \multirow{2}{*}{ Variable } & \multicolumn{2}{c}{ Sex behavior } & \multirow{2}{*}{ P-Value } & \multirow{2}{*}{ PR (95\% CI) } \\
\cline { 2 - 3 } $\begin{array}{lccc}\text { Education by parents } \\
\text { Good }\end{array}$ & $88(90.7)$ & $9(9.3)$ & 0.01 & 2.250 \\
Bad & $2(40.0)$ & $3(60.0)$ & & $(1.021-2.527)$ \\
Education by teachers & & & & \\
Good & $89(89.9)$ & $10(10.1)$ & 0.03 & 2.696 \\
Bad & $1(33.3)$ & $2(66.7)$ & & $(2.003-3.006)$ \\
Education by peers & & & & 3.119 \\
Good & $78(91.8)$ & $7(8.2)$ & 0.02 & $(2.087-3.875)$ \\
Bad & $12(70.6)$ & $5(29.4)$ & & \\
Education by social media & & & & 1.647 \\
Good & $85(91.4)$ & $8(8.6)$ & 0.01 & $(0.854-2.030)$ \\
Bad & $5(55.6)$ & $4(44.4)$ & & \\
\hline
\end{tabular}

Table 4. Multivariate Analysis of Sex Risk Behavior in Students

\begin{tabular}{|c|c|c|c|c|c|}
\hline \multirow[t]{2}{*}{ Variable } & \multirow[t]{2}{*}{ B } & \multirow[t]{2}{*}{$\mathrm{p}$} & \multirow[t]{2}{*}{ PR } & \multicolumn{2}{|c|}{$95 \% \mathrm{CI}$} \\
\hline & & & & Lower & Upper \\
\hline Sex education by parents & 1.179 & 0.000 & 6.836 & 2.051 & 13.762 \\
\hline Sex education by teacher & 1.425 & 0.038 & 1.241 & 1.002 & 6.300 \\
\hline
\end{tabular}




\section{DISCUSSION}

In this study, it is known that parents role in sex education will influence risky sexual behaviors. Parents as a role to give good sex education will protect adolescents from behaving sexually at risk by six times higher than parents not providing good sex education. The results of this study are in line with the research of Sari ${ }^{10}$ showing that $62.1 \%$ had good sex education from the family and did not risk sexual behavior. Theoretically, aspects that cause sexual behavior in adolescents include loose parental supervision and attention, free social patterns, and a free environment. Furthermore, other aspects that provide sexual stimuli include facilities such as television, mobile phones, computers, and mass media that families often provide without realizing the effects of their use. In this case, the critical role of parents is to be an effective managers, who can provide information, help make choices and provide guidance to the adolescents. ${ }^{11}$ Meanwhile, teachers play a role in providing the adolescents with correct information in a way that will positively affect their lives. ${ }^{12}$ Parents who teach about sex education to their children are more protective two times higher compared to parents whose children are at risk for sexual education

Furthermore, this study is based on variables related to sexual behavior, which is in line with the study by Masni, ${ }^{14}$ Sujarwati, ${ }^{11}$ Ulfah, ${ }^{15}$ and Sari. ${ }^{16}$ The role of sex education from parents affects adolescents sexual behavior so that adolescents will not have misperception in addressing their sexuality. ${ }^{17}$ Increased knowledge of sex education in youth guided by parents is essential in strengthening existing sexual education. ${ }^{18}$ Adolescent sex education counseling, adolescent sex education from adolescent health professionals, and adolescent counseling for parents are essential in the sex education approach. ${ }^{19}$ Besides, instilling religious values also need to be improved in the family to prevent poor teenage sexual behavior. ${ }^{20}$

The study's findings showed that there was a relationship between sexual education by teachers and sexual behavior in adolescents in high school. It is in line with those discovered by Usman \& Puar ${ }^{21}$ on teacher roles in the sex education process in adolescents. The teacher served as a Director coordinator (educating, teaching, guiding, coaching, advising, and becoming an innovator), pilot, researcher encouraging creativity and proper perspective direction, actors, emancipators, and evaluators. According to Rahman and Fachrudin ${ }^{22}$ treatments of sex education included aspects of consciousness conducted systematically from family, school, and the community to provide information about sexuality on the scope of the adolescents development. Furthermore, it can include sexual and social behavior, personal ability, family roles, school roles, community roles, and government roles and discussing issues and challenges to its development.

Besides, the role of parents is essential to prevent the occurrence of risks. ${ }^{23}$ The better the parent's relationship with his or her children is, the better the sexual behavior of the adolescent will be. ${ }^{24} \mathrm{~A}$ teacher is a role model exemplified by students in the school. ${ }^{25}$ Teachers should also provide the religious understanding and sexual education through interpersonal communication to adolescents to avoid premarital sex behavior. ${ }^{26}$

Thus, sex education in school should be carried out to receive pertinent information in terms of good sex behavior. ${ }^{27}$ moreover, training is also required by providing precise information on sex education and correct sex behavior provided by the youth health expert..$^{28}$ Learning about sexuality and adolescent sexual behavior should be put into the learning curriculum to get the correct information and avoid the wrong education and sex behavior in teenagers. ${ }^{29}$ With the training and the proper delivery of information to teachers as educators and tailored to the existing curriculum on adolescent sex education, it could prevent incorrect sex behavior in adolescents and avoid other sexual cases. The importance of parents, teachers, and social media becomes the basis for the elaboration of external factors that impact adolescent sexual behavior.

\section{CONCLUSION}

Based on the result of this study, it can be concluded that parents, teachers, and social media were associated with sexual education. Extensive sexual education from other trusted information could reduce pre-marital sexual activity among adolescents. Furthermore, elaborating external factors would implicate the good attitude and behavior in them.

\section{CONFLICT OF INTEREST}

The researchers declared no conflict of interest that might injure due to publicity, academic interests and competition, personal, religious, or political beliefs relevant to the topic discussed. 


\section{REFERENCES}

1. Kementerian Kesehatan RI. Survei Demografi dan Kesehatan Indonesia. Jakarta. 2013.

2. Purwaningtyas B, Wulandari RF. Analisis Pengaruh Pengetahuan Penyakit Menular Seksual Terhadap Pola Berpacaran Remaja di Wilayah Kecamatan Pare Kedir. Health Care Media. 2018; 3(4): 1-7.

3. Luthfie R. Fenomena Perilaku Seksual Pada Remaja (Sexual Behaviour Phenomena on Young People). Ceria. 2009: 1(1).

4. Gaol SMML, Stevanus K. Pendidikan Seks Pada Remaja. FIDEI J Teol Sist dan Prakt. 2019; 2(2): $325-43$. https://doi.org/10.34081/fidei.v2i2.76

5. Rochadi NW. Peran Teman Sebaya dan Media Informasi terhadap Perilaku Seks Pranikah Remaja. J Heal Stud. 2019; 3(1): 53-63. https://doi.org/10.31101/jhes.384

6. Badan Pusat Statistik. Survei Sosial Ekonomi Nasional (Susenas) Tahun 2010). Jakarta; 2015.

7. Mahmudah, Yaunin Y, Lestari Y. Faktor-Faktor yang Berhubungan dengan Perilaku Seksual Remaja di Kota Padang. J Kesehat Andalas. 2016; 5(2): 448-55. https://doi.org/10.25077/ika.v5i2.538

8. Ali Am, Asrori M. Psikologi Remaja Perkembangan Peserta Didik. 7th ed., Jakarta: Bumi Aksara; 2011.

9. Sunaryo D. Community Development Service on Educational and Health Sciences. Abdidas. 2020; 1(3): 8894.

10. Sari DJE. Hubungan Pendidikan Seks dalam Keluarga dengan Perilaku Seksual Remaja di SMA N 3 Bukit Tinggi Tahun 2012. Kesehat Masy STIKes Prima Nusant Bukit Tinggi. 2012; 3(2): 27-31. http://dx.doi.org/10.35730/jk.v3i2.169

11. Sujarwati S, Yugistyowati A, Haryani K. Peran Orang Tua dan Sumber Informasi dalam Pendidikan Seks dengan Perilaku Seksual Remaja pada Masa Pubertas di SMAN 1 Turi. J Ners dan Kebidanan Indonesia. 2016; 2(3): 112. http://dx.doi.org/10.21927/inki.2014.2(3).112-116

12. Oluwatoyin E, Modupe O. Risky Sexual Behaviour among Secondary School Adolescents in Ibadan North Local Government Area, Nigeria. IOSR J Nurs Heal Sci. 2014; 3(4): 34-44. https://doi.org/10.9790/1959. $\underline{03343444}$

13. Nursal, A DG. Faktor-faktor yang Berhubungan dengan Perilaku Seksual. Jurnal Kesehatan Masyarakat. 2008; 2(2). https://doi.org/10.24893/jkma.v2i2.29

14. Masni, Hamid SF. Determinan Perilaku Seksual Berisiko pada Remaja Makassar (Studi Kasus Santri Darul Arqam Gombara dan SMAN 6). Media Kesehatan Masyarakat Indonesia. 2018; 14(1): 68.

15. Ulfah M. Faktor-faktor yang Mempengaruhi Perilaku Seksual Pranikah pada Remaja SMP dan SMA di Wilayah $\begin{array}{llllll}\text { Eks-kota } & \text { Administratif } & \text { Cilacap. } & \text { Medisains. } & \text { 2019; } & \text { 16(3): }\end{array}$ http://dx.doi.org/10.30595/medisains.v16i3.3733

16. Sari DN, Darmana A, Muhammad I. Pengaruh Faktor Predisposisi, Pemungkin, dan Pendorong terhadap Perilaku Seksual di SMA Asuhan Daya Medan. Jurnal Kesehatan Global. 2018; 1(2): 53-60. https://doi.org/10.33085/jkg.v1i2.3943

17. Gunarsa SD. Psikologi Praktis: Anak, Remaja dan Keluarga. Jakarta: Gunung Mulia; 2008.

18. Sarwono, Wirawan S. Psikologi Remaja. Jakarta: Rajawali Press; 2013.

19. Lubis NL. Psikologi Kespro "Wanita EO Perkembangan Reproduksinya" Ditinjau dari Aspek Fisik dan Psikologinya. Jakarta: Kencana; 2013.

20. Athar S. Bimbingan Seks bagi Kaum Muda Muslim. Jakarta: Pustaka Zahra; 2004.

21. Usman, Puar AY. Bimbingan Sex untuk Remaja. Jakarta: Pustaka Antara; 1996.

22. Rahman A, Fachrudin. Pendidikan Seks di Sekolah. Jakarta: Fasco; 2000.

23. Yuhanah Y. Analisis Faktor yang Berhubungan dengan Perilaku Kespro Remaja pada Siswa SMA I Samaturu Kabupaten Kolaka. Jurnal Penelitian dan Pengabdian Masyarakat UNSIQ. 2020; 7(1): 48-54. https://doi.org/10.32699/ppkm.v7i1.1015

24. Karlina D, Mardjan, Taufik M. Hubungan antara Pengetahuan, Peran Guru Bimbingan Konseling (BK) dan Peran Orang Tua dengan Perilaku Seks Pranikah pada Remaja SMA di Desa Sungai Ringin Kecamatan Sekadau Hilir Kabupaten Sekadau Tahun 2013. 2013; 35. http://dx.doi.org/10.29406/jjum.v2i2.336

25. Nurzaman EW. Pengetahuan dan Perilaku Seksual Beresiko Remaja terhadap Kesehatan Reproduksi di SMK X Kecamatan Kebon Jeruk Jakarta Barat. Indonesia Jurnal Kebidanan. 2018; 2(1): 37-44. http://dx.doi.org/10.26751/ijb.v2i1.447

26. Otta LT, Rembang M, Harilama SH. Peranan Komunikasi Interpersonal Orang Tua dan Guru dalam Mencegah Perilaku Seks Pranikah Siswa Kelas XI di SMK Negeri 1 Modoinding. Acta Diurna Komun. 2018; 7(3): $1-15$.

27. Maimunah S. Implementasi Pendidikan Seks Berbasis Sekolah. Jurnal Ilmu Psikologi Terapan. 2019; 7(2): 4157. https://doi.org/10.22219/jipt.v7i2.8989 
28. Muninjaya, Gde A. AIDS di Indonesia : Masalah dan Kebijakan Penangulanggannya. Cetakan ke 1. Jakarta: EGC; 1999.

29. Miron M, G A Miron, D C. Bicara Soal Cinta, Pacaran, dan Seks kepada Remaja Panduan Guru Ë Orang Tua. Jakarta: Esensi; 2006. 